\title{
Implementation of the competence idea into the primary education in Ukraine - the reflective analysis based on the European Union benchmarks
}

\author{
Oleksandra Savchenko ${ }^{1}$, and Olena Lokshyna ${ }^{2, *}$ \\ ${ }^{1}$ Institute of Pedagogy of the NAES of Ukraine, Primary Education Department, Kyiv, 04053, Ukraine \\ ${ }^{2}$ Institute of Pedagogy of the NAES of Ukraine, Comparative Education Department, Kyiv, 04053, Ukraine
}

\begin{abstract}
The generation of the competence education idea in Ukraine based on the EU benchmarks is studied. It is underlined that the transformation of the national education into the competence base is a component of the European integration of Ukraine. The authors made conclusion that the Ukrainian education has gone from proclaiming the idea of the competence education, its conceptual justification to implementation. The research results evidence that the support of the competence idea at the level of educational policy is the most successful in Ukraine. At the same time, at the implementation level the competence idea meets a number of challenges due to the novelty of a clear correlation between strategic, didactic and methodological levels. The authors conclude that the problem of the formation of key competences, firstly of transversal or cross-curricular ones, remains underdeveloped; the aspects of crosscurricular links and integration of the education content requires further development; the level of assessing younger students in competencies is even more underdeveloped. On the other hand, the authors generalise that common globalization challenges, powerful integration processes in Europe, Europeanization affecting the European countries outside the EU borders contribute greatly to the synchronization of the education in Ukraine with EU standards.
\end{abstract}

\section{The competence education as the response of the European Union to the challenges of the globalised world}

Globalization and digital revolution have determined the need to transform the conceptual foundations of education - a knowledge model that had dominated in Europe for centuries could no longer satisfy the rapidly changing demands of the European societies. The competence-based education became an answer. "The shift to a digital, knowledge-based economy, prompted by new goods and services, will be a powerful engine for growth, competitiveness and jobs. In addition, it will be capable of improving citizens' quality of life and the environment... Every citizen must be equipped with the skills needed to live and work in this new information society" was stated in the Lisbon European Council Presidency Conclusions as of March 23 and 24, 2000. The Lisbon European Council proclaimed the necessity to develop a European framework of basic skills to be provided through lifelong learning as a key measure in Europe's response to globalisation and the shift to knowledge-based economies [1].

The process of the implementation of the competence idea in the European Union (EU) is long and multidimensional. The adoption of the European framework was proceeded by thorough research on the origin [2] and the essential characteristics of competences [3].

The discussions on the list of key competences needed for citizens of the modern world have been led by the leading international organizations. They are the Council of Europe with W. Hutmacher's Symposium Report "Key competencies in Europe" (1996) within "Secondary Education for Europe" Project; Organisation for Economic Cooperation and Development with "Definition and Selection of Competences (DeSeCo)" Project (1997-2003); the European Union "Key Competencies. A developing concept in general compulsory education" Eurydice Report (2002) [4], [5], [3].

The research and discussion period was completed with the adoption of the European Reference Framework of Key Competences for Lifelong Learning in 2006, which transformed the conceptual foundations of the European education. It is about changing the understanding of the mission of learning from the knowledge transition to the formation of individuals' personal characteristics of universal nature to be applied in a variety of rapidly changing contexts - individual, professional, social. To this end, not only knowledge but also skills / attitudes, as well as the ability to apply them in real life, are proclaimed as the components of the key competences.

\footnotetext{
* Corresponding author:luve2001@,hotmail.com
} 
The 2006 Reference Framework sets out eight key competences: communication in the mother tongue; communication in foreign languages; mathematical competence and basic competences in science and technology; digital competence; learning to learn; social and civic competences; sense of initiative and entrepreneurship; and cultural awareness and expression [6].

The adoption of the 2006 Reference Framework initiated the transformation of education into a competence basis in the EU Member States. In 2012 the monitoring results of this transformation were presented in the Eurydice Report "Developing Key Competences at School in Europe: Challenges and Opportunities for Policy" [3]. The methodological framework applied for the analysis can be regarded as valuable for the Ukrainian education that is under the same transformation.

In a highly competitive environment of the globalized world, the EU is making efforts to preserve its role as an economic leader, considering education as a key tool for building the knowledge economy. An updated European Reference Framework of Key Competences for Lifelong Learning was approved by a Council Recommendation as of May 22, 2018. Reflecting the new needs of the European societies, new emphasis is placed on the list of key competences and their interpretation. The 2018 Framework sets out the following eight key competences with a view to respond education to new political, economic and social realities: literacy competence; multilingual competence; mathematical competence and competence in science, technology and engineering; digital competence; personal, social and learning to learn competence; citizenship competence; entrepreneurship competence, cultural awareness and expression competence [7].

When analysing the 2018 Framework, you should pay attention to the following important points:

- multidimensionality of competences as efficient tool for modern life: the EU's position on understanding competence as a combination of knowledge, skills and attitudes was reaffirmed.

- lifelong and life wide perspective for competences acquisition: under the importance of lifelong learning, the idea of acquisition of key competences in a lifelong learning perspective, from early childhood throughout adult life, and through formal, non-formal and informal learning in all contexts, including family, school, workplace, neighbourhood and other communities is important;

- continuity in competences acquisition: a competence is defined as an open entity that an individual can develop within lifelong learning.

Thus, the adoption of the updated European Reference Framework for Key Competences for Lifelong Learning (2018) confirms the position on the invariability of competency education for EU - "In the knowledge economy, memorisation of facts and procedures is key, but not enough for progress and success. Skills, such as problem solving, critical thinking, ability to cooperate, creativity, computational thinking, and self-regulation are more essential than ever before in our quickly changing society. They are the tools to make what has been learned work in real time, in order to generate new ideas, new theories, new products, and new knowledge" stated in the Council Recommendation of 22 May, 2018 on key competences for lifelong learning [7].

The impact of this position on other European countries, including Ukraine, is equally important.

\section{Methodology and literature review}

The problem of competences has been essential for the Ukrainian education for almost twenty years, since the introduction of the competence idea at the European level. During this time, the Ukrainian scholars have made a solid input to the development of the competence education theory. In particular, the works of N. Bibik [8], I. Ermakov [9], L. Khoruzha [10], V. Lugovyi [11], O. Pometun, I. Rodigina, O. Savchenko, L. Vashchenko and others have enriched the understanding of the essential characteristics of competences, the nature of their origin.

The Ukrainian comparative educators have worked extensively on the dissemination of the European experience of the transformation of education into the competence base. For the first time O. Ovcharuk presented the European vision of the competence education in 2004 [13].

A long period of reflection and discussion has contributed to the systematization of the views of scholars, enriched the initial vision of the essence of the competences in the Ukrainian realities, and initiated the development of the technologies of the transformation of the national education on a competence basis.

The aim of the article is the reflective analysis of the competence education development in Ukraine from the perspective of the EU approach. The study was conducted through the lens of the EU analytical framework, based on the benchmarks proposed in the Eurydice Report "Developing Key Competences at School in Europe: Challenges and Opportunities for Policy" (2012) [14]. In particular, the following benchmarks have been applied:

(1) Competence idea support at the education policy level,

(2) New competence-based curriculum and

(3) Assessment of students in key competences.

The benchmark (1) "competence idea support at the education policy level" has been used for the analysis of the strategic/legislative/regulatory competence innovations; and the benchmarks; the benchmarks (2) "the new competence-based curriculum" and (3) "assessment of students in key competences" - to analyse the degree of the competence idea implementation into the educational practice in Ukraine. Together, all three benchmarks made it possible to view an aggregate picture of the implementation of the competence approach in Ukraine. Besides, the degree of synchronization of this process in Ukraine with the EU was analysed by the authors.

The data of the Eurydice Report "Developing Key Competences at School in Europe: Challenges and Opportunities for Policy" (2012) represent the state of 
implementation of the competence idea in the EU Member States after the European Framework adoption in 2006. In Ukraine, the systematic transformation of the national education into the competence base was initiated after the adoption of the Law of Ukraine "On Education" in 2017. Against this background, the benchmarks of the 2012 Eurydice Report appear to be valid for Ukraine.

The choice of the level of primary education in Ukraine is due to the fact that it is from the primary education level that the cardinal reform "New Ukrainian School" has been initiated after the adoption of the Law of Ukraine "On Education" (2017) [15].

The sources used for the analysis provide qualitative evidence in the forms of strategic benchmarks and legislative acts, existing national/international studies and reports. The selection of the sources depended on their appropriateness to the research idea of the paper.

In order to reach the aim of the paper the qualitative methods were used. The method of the literature review was used to find how scholars addressed the research problem. The analytical framework method was used to limit the scope of the relevant data by focusing on the selected benchmarks. The comparative method provided a base for the comparison of the competence idea implementation in EU and in Ukraine as well as of evaluation of the degree of synchronization of this process in Ukraine with the EU.

\section{The transformation of the primary education in Ukraine into the competence base under the European integration}

Ukraine has chosen the path of the European integration since independence declaration in 1991. Accordingly, the national education has been developing in the direction of synchronization with the European standards for almost thirty years. A competence idea has become one of the benchmarks of such synchronization.

Discussion on the competences for the national education started within the UNDP Ukraine projects "Education Innovation and Renewal for Improved Wellbeing and Poverty Reduction" (2002-2003) and "Education Policy and Peer Education" (2004). In the books "Reform Strategy for Education in Ukraine: Educational Policy Recommendations" (2004) and "Competence-based Approach in the Modern Education: World Experience and the Ukrainian Prospects (Education Policy Library)" (2004) the Ukrainian scholars under the umbrella of the Ministry of Education and Science of Ukraine launched the process of definition and selection of competences for the Ukrainian school [13], [8].

The Law of Ukraine "On Education" (2017) finalized the long-standing movement of the Ukrainian education towards the implementation of a competency idea. The Law declares that the goal of the secondary education is a comprehensive development, upbringing and socialization of a person capable to live in a society and interact with nature, to have a desire for selfimprovement and life-long learning, ready for conscious life choices and self-realization, responsibility, work activity and civic activity. The achievement of this goal is ensured through the formation of key competencies [15].

The primary school in Ukraine, as an integral part of the general secondary education, is also under transformation into a competence base. The State Standard of Primary General Education 2000 (being active for more than ten years) can be considered as the first normative document proclaiming the competence idea. At the same time, the traditional definition of the outcomes of school education in the knowledge \& skills format due to the underdeveloped theory of the competence-based approach did not contribute to it proper implementation [16].

Hard work of the Ukrainian scholars supported the development of the national competence education theory. The competence education has been proclaimed as a personal \& activity one that shifts the focus to a person's ability to take practical action in a particular context. The traditional "know what..." education result has been proposed to change into the "know how..." result. A new vision of the goal of education - from "formation of a comprehensively developed, harmonious personality" to "formation of an active, competent personality" - has been substantiated. The approaches to defining the content of learning - not "from the goal" but "from the result" - have been grounded. The development of a subject competence concept has been another valuable contribution of the Ukrainian scholars into the national theory of the competence education.

Based on the European experience (primarily the findings of the DeSeCo project) and the needs of the Ukrainian school, the following key competencies were identified: ability to learn (educational); civic; general cultural; competence in information and communication technologies; social; entrepreneurial; health saving [8]. It was the first attempt of the Ukrainian scholars in this area. They tried to adapt the European vision to the Ukrainian realities, i.e. the health saving competence was proposed in view of the ill-health indicators of the Ukrainian students.

In 2010, under the further modernization of the primary education in Ukraine, the Concept of the Second Generation of the State Standard of Primary General Education was developed. It became the theoretical basis for the development of the State Standard of Primary General Education (approved by the Cabinet of Ministers of Ukraine as of April 20, 2011).

The State Standard (2011) proclaims that the development of a child's personality is the priority of each educational field, taking into account the specifics of the subjects, the realization of the developmental and educational potential of the content and methods in the context of the competence approach. The document grounded on the European vision of the competence idea. In particular, the notions of "competence approach" in education, "key competence" and "cross-curricular competence" were officially defined taking into consideration the European approach.

It was first announced at the official level a list of cross-curricular and subject key competences that 
younger students should master: civic, communicative, social, aesthetic, mathematical and natural sciences competences [17].

The start of the systematic transformation of the primary education in Ukraine on a competence basis can be regarded as the most important positive that have been achieved with the adoption of the second generation of the State Standard of Primary General Education. The state of the Ukrainian education theory under the European integration provided the substantiation of the following fundamental principles of the competence education:

- the use of a competence always occurs in a particular context (in a particular educational situation);

- a competence is always a result that characterizes what an individual can do, rather than describing the process in which he/she acquires that competence (for example, a student does not say "I read, I wrote ..." but shows what exactly he/she can);

- clearly measured and approved standards are required to measure an individual's ability to exercise competence, taking into account what an individual can do at a specific time.

The new Law of Ukraine "On Education" (2017) enshrined the idea of the competence education. The Law declares that the goal of the secondary education is a comprehensive development, upbringing and socialization of a person capable to live in a society and interact with nature, to have a desire for selfdevelopment and life-long learning, be ready for conscious life choices and self-realization, responsibility, work and community activities.

The achievement of this goal is ensured through the formation of the following key competencies: fluency in the state language; ability to communicate in mother tongue (in case it differs from the state language) and foreign languages; mathematical competence; competence in the area of natural sciences, engineering and technology; innovation; ecological competence; information and communication competence; life-long learning; civic and social competences related to the ideas of democracy, justice, equality, human rights, wellbeing and a healthy lifestyle, with the awareness of equal rights and opportunities; cultural competence; entrepreneurship and financial literacy [15].

The Law on Education (2017) has become the regulatory framework for further competence-oriented reforming primary education in Ukraine. During the 2016-18 years, a new State Standard of Primary Education and two Typical Educational Programmes, in which key and subject competences have been defined as educational outcomes, have been developed and approved.

The State Standard of Primary Education (2018) proclaims that the goal of primary education is the comprehensive development of a child, his/her talents, abilities, competences and transversal skills in accordance with age, individual psychophysiological characteristics and needs, formation of values, development of autonomy, creativity and curiosity [18].

The list of key competences named in the Standard is identical with the list in the Law. At the same time, the
State Standard of Primary Education specifies the content of competences, taking into account the specific tasks of this level of education. In particular,

- Fluency in the state language competence for primary school implies the ability to express verbally and in writing thoughts, feelings, clearly and reasonably explain the facts, as well as a love of reading, a sense of the beauty of the word, an awareness of the role of the language for effective communication and cultural expression, Ukrainian readiness language as a mother tongue in different situations of life;

- Ability to communicate in mother tongue (in case it differs from the state language) and foreign languages involves active use of the mother tongue in various communication situations, including in everyday life, educational process, cultural life of the community, the ability to understand simple expressions in a foreign language, to communicate in appropriate situations intercultural communication skills;

- Mathematical competence involves the identification of simple mathematical dependencies in the surrounding world, modelling processes and situations using mathematical relations and measurements, awareness of the role of mathematical knowledge and skills in the personal and public life of man;

- Competences in the area of sciences, engineering and technology. They presuppose the formation of curiosity, the desire to seek and propose new ideas, independently or in a group to observe and explore, formulate assumptions and draw conclusions from the experience, to know themselves and the world through observation and research; Innovation involves being open to new ideas, initiating change in a close environment (class, school, community, etc.), forming knowledge, skills, attitudes, which are the basis of a competency-based approach, provide further ability to successfully learn, pursue a professional activity, feel part of community and take participation in community affairs;

- Ecological competence implies awareness of the basics of environmental management, adherence to the rules of environmental behaviour, saving the use of natural resources with an understanding of the importance of nature conservation for the sustainable development of society;

- Information and communication competence involves mastering the digital literacy framework for development and communication, the ability to safely and ethically use the means of information and communication competence in learning and other life situations;

- Lifelong learning involves mastering the skills needed for further learning, organizing one's own learning environment, obtaining new information to use to assess learning needs, defining one's own learning goals and ways to achieve them, learning to work independently and in a group;

- Civic and social competences related to the ideas of democracy, justice, equality, human rights, well-being and a healthy lifestyle, awareness of equal rights and opportunities include: the ability to act as a responsible citizen and participate fully in public and social life, including schools and class, based on an understanding of social, economic and political concepts and 
sustainable development, a critical appraisal of major events in national, European and world history, and respect for human rights us and the rule of law, the appreciation of the cultural diversity of different peoples, and the identification of oneself as a citizen of Ukraine, showing respect for others and tolerance, being able to cooperate constructively, sympathize and act in conflict situations, including in relation to various forms of discrimination. Careful attitude towards personal, social and physical well-being and health, maintaining a healthy lifestyle; understanding the rules of conduct and communication that are generally accepted in different communities and environments, the ability to act in the face of uncertainty and multitasking;

- Cultural competence involves involvement in various types of artistic creativity (fine arts, music and other arts) through the discovery and development of natural abilities, creative expression of personality;

- Entrepreneurship and financial literacy imply initiative, a willingness to take responsibility for their own decisions, the ability to organize their activities to achieve goals, an awareness of the ethical values of effective cooperation, a willingness to put into practice the ideas that have been initiated, to make their own decisions [18].

The experience of the recipients of education, their needs, which motivate learning, knowledge and skills, which are formed in different educational environment (school, family), different social situations determining formation of attitude to them are proclaimed as the basis for the formation of key competences.

The Standard defines the requirements to the mandatory learning outcomes and competencies for students in the following educational areas: language \& literature (Ukrainian language and literature, languages and literature of relevant indigenous and national minorities; foreign language education); mathematical; science; engineering; informative; social and health saving; civic and history; art; physical education.

It should be emphasized that introduction of new educational terminology of the education results reflects a change of the goal of education, which becomes activity-efficient. This necessitates rethinking of selection of content, ensuring its closeness to the vital needs of children, reconciling the complexity and volume of the learning material with the predicted results.

The new educational outcomes is another innovation of the State Standard of Primary Education (2018). The content was the source category of the State Standard of Primary Education 2011. It defined the instruction results according to the themes and scope of content.

The content design of the 2018 Standard is fundamentally different, i.e. the instrumental knowledge being the basis to master the methods of action, prevails in teaching. If educational outcomes are the starting point in defining the content of primary education, then the competence approach becomes a means of achieving new quality of education. Under these conditions, teachers must objectively distinguish between learning process and learning outcomes, and students gradually learn to distinguish between knowledge of facts, phenomena, and knowledge of action.

The focus on different types of integration we consider as another advantage of the competence-based State Standard of Primary Education 2018. It provides the ability to combine subject learning with integrated courses in typical educational programmes.

Therefore, the new 2018 State Standard of Primary Education is based on new conceptual framework that is in line with the European competence approach. It opens opportunities for the development of young personalities able to successfully live, work, self-develop in a fastpaced and open world.

The Typical Primary Education Programmes with the lead of O. Savchenko are clearly synchronized with State Standard in terms of the competence idea. Specifically, the "logical consistency and sufficiency of students' acquisition of subject competencies" and "interconnected development of key and subject competences in each educational area" are defined among the principles of Programme design.

In the 2018 State Standard of Primary Education the general mandatory results are defined in the key competences and educational area format. In the Typical Education Programmes the specific expected results are defined and presented along the content lines, taking into account the opportunities of each educational area to form key and subject competencies [19], [20].

\section{Synchronization of the education in Ukraine with the EU benchmarks}

Evaluation of the degree of the synchronization of the education in Ukraine with the EU benchmarks made it possible to reach a number of important conclusions.

The competence education is recognized as a priority in Ukraine like in the EU. Ukraine, as a European state, is under the influence of the similar with the EU globalisation challenges, which makes competence education relevant. Besides, the implementation of the European competence idea in Ukraine is facilitated by the European integration, which is enshrined in the Constitution of Ukraine.

At the same time, it should be noted that there is no separate strategy for implementation of the competence education in Ukraine - the competence idea is a part of the comprehensive strategy of school education reforming "New Ukrainian School".

It is necessary to state the synchronization of the conceptual vision of the competence education in Ukraine with the EU. The competence idea adopted in Ukraine is in line with the European vision.

The provided in the Table 1 comparison of the key competences proclaimed at the policy level in EU and in Ukraine confirms this statement.

At the level of the primary education key documents in Ukraine the list of key competences is identical to the list approved by the Law "On Education" (2017). This effectively aligns the competences of the primary education in Ukraine with the European standards.

However, it should be noted that the adoption of the renewed 2018 European Reference Framework of Key 
Competences for Lifelong Learning aimed at responding to the new demands of the European societies opens prospects for Ukraine in the area of conceptual architecture.

Table 1. Key competences for lifelong learning proclaimed at the policy level in the EU (2006 vision) and in Ukraine.

\begin{tabular}{|c|c|}
\hline $\begin{array}{c}\text { List of key competences } \\
\text { indicated in the European } \\
\text { Reference Framework of } \\
\text { Key Competences for } \\
\text { Lifelong Learning (2006) } \\
\text { [6] } \\
\end{array}$ & $\begin{array}{l}\text { List of key competences } \\
\text { indicated in the Law of Ukraine } \\
\text { "On Education" (2017) [15] }\end{array}$ \\
\hline $\begin{array}{c}\text { Communication in the } \\
\text { mother tongue }\end{array}$ & Fluency in the state language \\
\hline $\begin{array}{c}\text { Communication in foreign } \\
\text { languages }\end{array}$ & $\begin{array}{c}\text { Ability to communicate in mother } \\
\text { tongue (in case it differs from the } \\
\text { state language) and foreign } \\
\text { languages }\end{array}$ \\
\hline \multirow{3}{*}{$\begin{array}{l}\text { Mathematical competence } \\
\text { and basic competences in } \\
\text { science and technology }\end{array}$} & Mathematical competence \\
\hline & 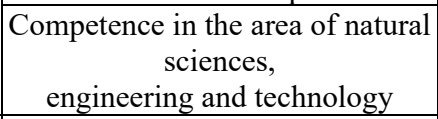 \\
\hline & $\begin{array}{l}\text { Innovation; ecological } \\
\text { competence }\end{array}$ \\
\hline Digital competence & $\begin{array}{c}\text { Information and communication } \\
\text { competence }\end{array}$ \\
\hline Learning to learn & Life-long learning \\
\hline $\begin{array}{l}\text { Social and civic } \\
\text { competences }\end{array}$ & $\begin{array}{c}\text { Civic and social competences } \\
\text { related to the ideas of democracy, } \\
\text { justice, equality, human rights, } \\
\text { well-being and a healthy lifestyle, } \\
\text { with the awareness of equal rights } \\
\text { and opportunities }\end{array}$ \\
\hline $\begin{array}{c}\text { Sense of initiative and } \\
\text { entrepreneurship }\end{array}$ & $\begin{array}{c}\text { Entrepreneurship and financial } \\
\text { literacy }\end{array}$ \\
\hline $\begin{array}{c}\text { Cultural awareness and } \\
\text { expression }\end{array}$ & Cultural competence \\
\hline
\end{tabular}

As can be seen from Table 2, it is about further synchronizing both the list and the essence of the key competences that are necessary for life in Europe in the $21^{\text {st }}$ century.

Is it important that Ukraine applies the European implementation algorithm. It comprises the comprehending the essence of competencies; development of methodological/strategic benchmarks and legislative/normative base; technologies for practical implementation.

The monitoring of the implementation of the announced initiatives to track benchmarks is an important component of this algorithm in the EU. In particular, the results of such monitoring in the Eurydice Report "Developing Key Competences at School in Europe: Challenges and Opportunities for Policy" (2012) made it possible to assess the degree of the process, see the systemic challenges that need to be addressed. Unfortunately, the practice of monitoring the implementation of the announced/started reforms has not yet become mandatory in Ukraine.

We consider broad consultations (on-line consultations, position papers, consultation meetings, expert seminars) initiated by the European Commission on the review of the Recommendations on Key
Competences for Lifelong Learning (2006) as a promising tool for the educational policy in Ukraine.

Table 2. Key competences for lifelong learning proclaimed at the policy level in Ukraine and in the EU (2018 vision).

\begin{tabular}{|c|c|}
\hline $\begin{array}{l}\text { List of key competences } \\
\text { indicated in the Law of } \\
\text { Ukraine "On Education" } \\
\text { (2017) [15] }\end{array}$ & \begin{tabular}{|c} 
List of key competences \\
indicated in the European \\
Reference Framework of \\
Key Competences for \\
Lifelong Learning (2018) \\
[7]
\end{tabular} \\
\hline Fluency in the state language & Literacy competence \\
\hline $\begin{array}{c}\text { Ability to communicate in } \\
\text { mother tongue (in case it differs } \\
\text { from the state language) and } \\
\text { foreign languages }\end{array}$ & Multilingual competence \\
\hline Mathematical competence & \multirow{2}{*}{$\begin{array}{l}\text { Mathematical competence } \\
\text { and competence in science, } \\
\text { technology and engineering }\end{array}$} \\
\hline $\begin{array}{c}\text { Competence in the area of natural } \\
\text { sciences, } \\
\text { engineering and technology } \\
\end{array}$ & \\
\hline $\begin{array}{l}\text { Innovation; ecological } \\
\text { competence }\end{array}$ & \\
\hline $\begin{array}{l}\text { Information and communication } \\
\text { competence }\end{array}$ & Digital competence \\
\hline Life-long learning & \multirow{2}{*}{$\begin{array}{c}\text { Personal, social and learning } \\
\text { to learn competence }\end{array}$} \\
\hline Civic and social competences & \\
\hline $\begin{array}{c}\text { related to the ideas of democracy, } \\
\text { justice, equality, human rights, } \\
\text { well-being and a healthy } \\
\text { lifestyle, with the awareness of } \\
\text { equal rights and opportunities }\end{array}$ & Citizenship competence \\
\hline $\begin{array}{l}\text { Entrepreneurship and financial } \\
\text { literacy }\end{array}$ & $\begin{array}{l}\text { Entrepreneurship } \\
\text { competence }\end{array}$ \\
\hline Cultural competence & $\begin{array}{l}\text { Cultural awareness and } \\
\text { expression competence }\end{array}$ \\
\hline
\end{tabular}

The practice of application of the national-based approaches to implement the competence education idea by the EU Member States within the framework of EU Framework is valuable for Ukraine as well. A number of countries (Austria, Lithuania, Poland and Spain) launched national strategies across all eight key competences proposed by the European Reference Framework of Key Competences for Lifelong Learning 2006. Others (as on 2012) in their national strategies focused on several key competencies, including digital and entrepreneurial ones [14]. From the very beginning, Ukraine has taken a holistic approach, introducing a full list of key competencies identified by legislation [15]. It opens up new possibilities and at the same time creates additional difficulties.

The competence-based curriculum is a new reality for both EU and Ukraine. The challenge here is a new content that would provide the formation of key competences, primarily of the transversal ones.

The problem of integrating the content of education to form these competences exists both in the EU Member States and in Ukraine. In particular, the Eurydice Report "Developing Key Competences at School in Europe: Challenges and Opportunities for Policy" (2012) notes low levels of integration with respect to digital competencies in teaching mathematics, science and languages, even in countries where computer availability is high [14]. For Ukraine, the problem of the 
formation of transversal/cross-curricular competences by means of the integrated content is a new one. Proper teacher training is equally important.

The assessment of students in the transversal competences is one of the most unresolved issues for Ukraine. The EU Member States started the process of developing tests for assessing transversal competences much earlier. Therefore, their experience requires careful study.

\section{Conclusions}

Speaking about the transformation of the primary education in Ukraine into the competence base, we should state its dynamic movement from the stage of proclaiming the idea of the competence education, its conceptual justification to implementation.

There is a clear consistency in the implementation of the competence approach at the policy level (benchmark 1). The competence idea is reflected in the key state documents - in the Law of Ukraine "On Education" (2017), the State Standard for Primary Education (2018), and Typical Programmes. This testifies to the intention of the state to implement of the competence idea, the priority of the competence education for Ukraine.

It should be emphasized that the support of the competence idea at the level of educational policy is the most successful in Ukraine.

The approval of the new competence-based curriculum - the National Standard of Primary Education (2018), as well as Typical Primary Education Programmes is the achievement at the implementation level (benchmark 2). The prioritization of the outcome component in the structure of these documents is the defining feature.

At the same time, since the implementation of the new competency-based curriculum has been just started, this creates a number of challenges. Primarily, they are due to the novelty of a clear correlation between strategic, didactic and methodological levels.

The question of the need of the presence of the whole list of key competences identified by the Law "On Education" in the primary school curriculum requires special reflection - should all of them be the result of learning at this education stage?

The essence of a key competence as an integrated entity involves reaching a cross-curricular level. A competence approach to education requires the use of different types of integration of the educational content. In particular, in the typical educational programs for grades 1-2 and 3-4 of general secondary education with the lead of O. Savchenko, the subject education is combined with the integrated courses. For example, the new course "I'm Exploring the World" combines five educational areas and is due for instruction in grades 1-4 [21], [22].

At the same time, the problem of the formation of key competences, firstly of transversal or crosscurricular ones, remains at the methodological level; the aspects of cross-curricular links and integration of the education content requires further development.

The level of assessing younger students in competencies is even more underdeveloped (benchmark
3). Traditionally, the learning outcomes have always been recorded at the subject level. Today, the development of valid tools for assessing students in transversal competences is a serious challenge.

Additionally, the following questions remain relevant:

- When key competences mastered by younger students can be subject of the national level assessments?

- Which evaluation tool is best to assess the transversal competences of the younger students?

- How to assess students' mastering of value orientations that are integral components of key competences?

Finally, an effective feedback tool has not yet been worked out, the process is still discrete.

Thus, in the context of the European integration, the nature of the development of the Ukrainian education is determined by the strategic benchmarks of the EU. The transformation of the Ukrainian primary education into a competence base is a prime example.

Of course, we should note the lag in the implementation of the competence idea in Ukraine in time compared to the EU countries (the competence education in Ukraine was enshrined at the legislative level by the Law of Ukraine "On Education" only in 2017). Ukraine is not a member of the EU and therefore does not directly fall within the requirements / mechanisms / methods applied within the EU.

However, common globalization challenges, powerful integration processes in Europe, Europeanization affecting the European countries outside the EU borders contribute greatly to the synchronization of the education in Ukraine with EU standards.

\section{References}

1. The Lisbon European Council 23-24 March 2000 Presidency Conclusions (European Council, Lisbon, 2000),

https://www.europarl.europa.eu/summits/lis1_en.ht m. Accessed 29 Dec 2019

2. M.K. Smith, Competence and Competency (infed, 1996), http://www.infed.org/biblio/b-comp.htm. Accessed 29 Dec 2019

3. Key Competencies. A developing concept in general compulsory education. Eurydice Survey 5. (European Commission, Directorate-General for Education and Culture, Eurydice, Brussels, 2002)

4. W. Hutmacher, Key Competences for Europe. Report presented at the Symposium "Key Competences in Europe", Council for Cultural Cooperation, Council of Europe, Berne, Switzerland, 27-30 March 1996

5. Definition and Selection of Competencies: Theoretical and Conceptual Foundations (DeSeCo). Background Paper (OECD, DeSeCo, Switzerland, 2001)

6. Recommendation of the European Parliament and of the Council of 18 December 2006 on key competences for lifelong learning, OJ. L 394, 10-18 (2006) 
7. Council Recommendation of 22 May 2018 on key competences for lifelong learning (Text with EEA relevance) ST/9009/2018/INIT, OJ. C 189, 1-13 (2018)

8. N. Bibik et al., Kompetentnisnyi pidkhid u suchasnii osviti: svitovyi dosvid ta ukrainski perspektyvy. Biblioteka $z$ osvitnoi polityky (Competency-based approach in modern education: world experience and Ukrainian prospects: Educational policy series). (K.I.S., Kyiv, 2004)

9. I.G. Yermakov (ed.), Zhy 'ttyeva kompetentnist osoby 'stosti: vid teoriyi do prakty 'ky' (The life competence of a personality: from theory to practice). (Tsentrion, Zaporizhzhia, 2005)

10. L.L. Khoruzha, Pedagogichna osvita: teoriya i prakty`ka 7, 178-183 (2007)

11. V. Lugovyi, Pedagogika i psy’xologiya 2, 13-26 (2009)

12. I. Rodygina, Kompetentnisno spryamovany`j pedagogichny` $j$ proces (Competence-oriented pedagogical process) (2008), https://osvita.ua/school/method/1963/. Accessed 8 Jan 2020)

13. O. Ovcharuk, in Reform Strategy for Education in Ukraine: Educational Policy Recommendations (K.I.S., Kyiv, 2003), pp. 13-41

14. Developing Key Competences at School in Europe: Challenges and Opportunities for Policy. Eurydice Report (European Commission, EACEA, Eurydice, Brussels, 2012)

15. Zakon Ukrainy Pro osvitu (The Law of Ukraine On Education) (2017), https://zakon.rada.gov.ua/laws/show/2145-19. Accessed 28 Nov 2019

16. Postanova Kabinetu Ministriv Ukrainy vid 16 ly`stopada 2000 r. № 1717 Pro perexid zagal'noosvitnix navchal'ny`x zakladiv na novy` $j$ zmist, strukturu i 12-richny j termin navchannya (Resolution of the Cabinet of Ministers of Ukraine as of November 16, 2000, No. 1717 On the Transition of the Secondary Education Institutions into a New Content, Structure and 12-years Duration of Instruction) (2000), https://zakon.rada.gov.ua/laws/show/1717-2000$\%$ D0\%BF. Accessed 9 Jan 2020

17. Postanova Kabinetu Ministriv Ukrainy vid 20 kvitnia 2011 r. № 462 Pro zatverdzhennia Derzhavnoho standartu pochatkovoi zahalnoi osvity (Resolution of the Cabinet of Ministers of Ukraine as of April 20, 2011, No. 462 On the Adoption of the State Standard of Primary General Education (2011), https://zakon.rada.gov.ua/laws/show/4622011-\%D0\%BF. Accessed 8 Jan 2020

18. Postanova Kabinetu Ministriv Ukrainy vid 21 liutoho 2018 r. № 87 Pro zatverdzhennia Derzhavnoho standartu pochatkovoi osvity (Resolution of the Cabinet of Ministers of Ukraine as of February 21, 2018, No. 87 On the Adoption of the State Standard of Primary General Education
(2018), https://zakon.rada.gov.ua/laws/show/872018-\%D0\%BF. Accessed 8 Jan 2020

19. Typova osvitnia prohrama dlia 1-2 klasiv zakladiv zahalnoi serednoi osvity pid kerivnytstvom Savchenko O.Ia. (The typical educational program for grades 1-2 of general secondary education with the lead of Savchenko O.Ya.) (2019), https://osvita.ua/doc/files/news/659/65920/5d9d8feb 1ce4f316467013_1.pdf. Accessed 8 Jan 2020

20. Typova osvitnia prohrama dlia 3-4 klasiv zakladiv zahalnoi serednoi osvity pid kerivnytstvom Savchenko O.Ia. (The typical educational program for grades 3-4 of general secondary education with the lead of Savchenko O.Ya.) (2019), https://mon.gov.ua/storage/app/media/zagalna $\% 20$ se rednya/programy-1-4-klas/2019/11/3-4-dodatki.pdf. Accessed 3 Jan 2020 